\title{
FAKTOR-FAKTOR YANG BERHUBUNGAN DENGAN STATUS GIZI PADA ANAK BALITA DI LINGKUNGAN 15 KELURAHAN PEKAN LABUHAN
}

\author{
Pahala Maringan J. Simangunsong*, Masryna Siagian Siagian, Siti Hadijah Siregar Fakultas \\ Kesehatan Masyarakat Universitas Prima Indonesia \\ *email: pahalamj@icloud.com
}

\begin{abstract}
Nutrition status is health relating to the use of eating pattern by body. Belawan Public Health center ranked 4 with malnutrition status with the total of 196 (3.1\%) below Medan Labuhan, Medan Helvetia, and Medan Tuntungan. Malnutrition mostly occured at environment 15 that is, 8 babies suffering from malnutrition out of 2.047 babies, and 2 babies having bad nutrition. The research aims at finding out the relationship between dependent and independent variables at environment 15, families of Pekan Labuhan, Pekan Labuhan regency of Medan Labuhan in 2015. The research method is Cross sectional using total sampling techniqe that 40 familes were taken as samples having babies. The research data were taken by performing home visits from house to house, visiting to integrated post service (Posyandu) with interview guide and questionnaires. The result of the study showed that 2 respondents (5\%) experienced malnutrition, 8 respondents (20\%) suffered from less nutrition and 30 respondents (75\%) experienced good nutrition. Based on bivariate analysis, it was found that there was a dependent variable not having a significant relationship with baby nutrition status; that is, variable of family income $(\rho$-value $=0.108)$ and 4 independent variables have a significant relationship with baby nutrition status; that is, variable of mother's $(\rho$-value $=0.000)$, and the number of family member $(\rho$-value $=0.027)$. The research concludes that there is a significant relationship between mother knowledge, mother attitude, mother education and the number of family members on the baby nutrition status. Public Health Center is suggested to provide counseling to mothers having babies continually Mothers are suggested to visit Public Health Center routinely to check up their baby nutrition.
\end{abstract}

\section{Keywords: Todler, Nutrition Status}

\section{PENDAHULUAN}

Gizi mempunyai peranan penting dalam daur kehidupan. Setiap tahap daur kehidupan terkait dengan zat gizi yang berbeda, semua orang sepanjang kehidupan membutuhkan zat gizi yang sama, namun dengan jumlah yang berbeda dari makanan, melalui peranan fsiologis yang spesifik dan tidak tergantung pada zat gizi yang lain, sangat dibutuhkan untuk hidup dan sehat (Achadi, 2007).

Pada saat ini, Indonesia menghadapi masalah gizi ganda, yaitu masalah gizi kurang dan masalah gizi lebih. Masalah gizi kurang pada umumnya disebabkan oleh kemiskinan,kurangnya persediaan pangan, kurang baiknya kualitas lingkungan

(sanitasi),kurangnya pengetahuan masyarakat tentang gizi, menu seimbang dan kesehatan dan adanya daerah miskin gizi. Kelompok bayi dan balita merupakan kelompok yang sering mengalami masalah gizi yaitu masalah gizi kurang (Almatsier,2009).

Status gizi adalah keadaan kesehatan yang berhubungan dengan penggunaan makanan oleh tubuh. (Adriani, 2012).Selanjutnya Supariasa (2011) menjelaskan bahwa status gizi merupakan keseimbangan dalam bentuk variabel tertentu, atau perwujudan dari nutrisi dalam bentuk variabel tertentu. Menurut Maryuni (2009), balita merupakan salah satu golongan paling rawan gizi.

Pada usia(0-59 bulan) balita dikatakan sebagai usiayang rawan karena rentang waktu ini anak masih sering sakit, anak merupakan konsumen pasif yang sangat bergantung kepada orang tuanya serta sering terdapat keluhan kurang nafsu makan.

Dinegara-negara berpendapatan rendah, rata-rata $3 \%$ anak balita mengalami gizi buruk dan gizi kurang yang disebabkan karena kurang energi protein.Jadi dalam setiap waktu terdapat 10 juta anak-anak pra-sekolah yang menderita gizi buruk. Biasanya $25 \%$ atau 80 juta anak-anak pra-sekolah diperhitungkan menderita gizi kurang yang sedang dan masih ada 40-45 \% atau 130-60 juta anak- 
anak lain yang diakui secara umum, menderita gizi kurang yang ringan, Masalah Kesehatan Masyarakat sudah dianggap serius bila prevalensi BB/TB kurus antara 10\% - 14,9\% dan dianggap kritis $\geq 15 \%$. (WHO, 2010)

Salah satu sasaran pembangunan yang akan dicapai adalah menurunkan prevalensi gizi kurang menjadi setinggitingginya $15 \%$ dan menurunkan prevalensi pendek menjadi setinggi-tingginya 32\%. Dan jumlah balita gizi buruk dan kurang menurut hasil Riskesdas 2013 masih sebesar $19,6 \%$ di bandingkan dengan tahun 2014 sebesar 15\% (DepKes, 2014)

Prevalensi gizi buruk berat tertinggi terdapat di 5 provinsi yaitu Di Aceh (<-3,0 SB), Sumatera Utara (-3,0 SB hingga $-2,0$ $\mathrm{SB})$, Sumatera Barat $(>10 \%)$, NTB,NTT dan Kalimantan Barat (<-10\%). Pada umumnya masalah gizi lebih banyak terjadi di daerah perdesaan daripada di daerah perkotaan.Adapun faktor yang berpengaruh dalam masalah gizi tersebut adalah kurangnya pengetahuan ibu tentang pola asuh, terutama dalam praktek pemberian makan, misalnya pemberian makanan pendamping ASI (MP-ASI) dan pemberian makanan sesudah bayi disapih serta tentang pemeliharaan lingkungan yang sehat (Almatsier, 2009).

Pada Profil Kesehatan Kota MedanTahun 2014, dari 1.048 .497 balita yang ditimbang, terdapat $14.387(1,40 \%)$ balita yang menderita gizi kurang,sedangkan yang menderita gizi buruk ada sebanyak 1.247(0,11\%). Dibandingkan tahun 2012, persentase balita gizi kurang sebesar 3,70\%, artinya mengalami penurunan sebesar $2,3 \%$. Sedangkan penderita gizi buruk tahun 2012 dan tahun 2013 tidak mengalami perubahan atau tetap.(Kesehatan Kota Medan, 2014)

Berdasarkan data dari Dinas Kesehatan Kota Medan (2015), diketahui bahwa terdapat $3.223(2,74 \%)$ balita yang menderita gizi kurang dan $138(0,12 \%)$ menderita gizi buruk dari 117.727balita yang ditimbang pada tahun 2014.Puskesmas Medan Belawan

\section{METODE PENELITIAN}

Jenis penelitian yang digunakan adalah survei analitik dengan desain cross sectional yaitu dimana variabel independen dan dependen diteliti secara bersamaan menduduki urutan nomor empat dengan status gizi kurang terbanyak yang berjumlah 196 (3,10\%) setelah Medan Labuhan, Medan Helvetia dan Medan Tuntungan. Sementara berdasarkan hasil survei awal di PuskesmasMedan Belawan tahun 2015 memiliki 150 balita gizi kurang. Dibandingkan tahun 2014, persentasi balita gizi kurang tidak mengalami penurunan. Angka ini menunjukkan bahwa jumlah balita yang memiliki status gizi kurang cukup tinggi. Di lihat dari segi besaran masalah yang pada umumnya disebabkan oleh kemiskinan, kurangnya persediaan pangan dan kurang baiknya kualitas lingkungan. (Dinas Kesehatan Kota Medan, 2015)

Pada Puskesmas Pekan Labuhan Kecamatan Medan Labuhan yang terdiri dari 2 Kelurahan yaitu Kelurahan Pekan Labuhan dan Kelurahan Nelayan Indah pada tahun 2015 bulan Mei, jumlah balita yang mengalami gizi buruk sebanyak 7 orang dan yang mengalami gizi kurang sebanyak 24 orang dari 2.047 balita yang ada di wilayah kerja Puskesmas Pekan Labuhan, dimana gangguan gizi yang paling banyak terjadi di Kelurahan Pekan Labuhan lingkungan 15, yaitu 4 orang balita mengalami gizi kurang dan 1 balita mengalami gizi buruk, dari umur (0-59 Bulan) (Puskesmas Pekan Labuhan, 2015).

Berdasarkan survey awal yang dilakukan oleh peneliti di Lingkungan 15 Kelurahan Pekan Labuhandari hasil wawancara dan observasi dari 15ibu, hanya 4 ibu yang pengetahuan dalam memberikan kebutuhan gizi dengan baik, dari segi pemberian makanan terdapat 5 ibu yang mempunyai balita dengan keadaan masalah gizi dengan status gizi kurang dan 3balita mengalami gizi buruk yaitu anak balita berumur 5 tahun dengan tinggi badan $95 \mathrm{~cm}$ dan dengan berat badan $11,5 \mathrm{~kg}$, dan balita berumur 2 tahun dengan tinggi badan $74 \mathrm{~cm}$ dan dengan berat badan $7,5 \mathrm{~kg}$, dan 2 tahun dengan tinggi badan $70 \mathrm{~cm}$ daan dengan tinggi badan $6,3 \mathrm{~kg}$.

untuk mengetahui Faktor-Faktor Yang Berhubungan Dengan Status Gizi Pada Anak Balita Di Lingkungan 15 Kelurahan Pekan Labuhan Tahun 2015. 
Populasi dalam penelitian ini adalah keseluruhan ibu yang memiliki balita di Lingkungan 15 Kelurahan Pekan Labuhan sebanyak 40 orang.

Teknik pengambilan sampel dengan menggunakan metode total sampling. Total sampling adalah teknik pengambilan sampel dimana jumlah populasi menjadi sampel penelitian. Jumlah sampel dalam penelitian ini adalah ibu-ibu yang memiliki balita yaitu 40 orang.

Pengambilan data dilakukan dengan menggunakan data primer dan data

Berdasarkan hasil penelitian yang dilakukan pada tanggal 23 November sampai tanggal 19 Desember tahun 2015. yang bertujuan untuk mengetahui Faktor-

Faktor Yang Berhubungan Dengan Status Gizi Pada Anak Balita Di Lingkungan 15 skunder, data primer merupakan data yang diperoleh langsung dari responden sedangkan data skunder merupakan data yang diambil dari pihak yang berwewenang melakukan pencatatan data mengenai FaktorFaktor Yang Berhubungan Dengan Status Gizi Pada Anak Balita Di Lingkungan 15 Kelurahan Pekan Labuhan Tahun 2015.

\section{HASIL PENELITIAN}

Dengan Status Gizi Pada Anak Balita Di Lingkungan 15 Kelurahan Pekan Labuhan diperoleh hasil sebagai berikut :

Tabel 1

Karakteristik Responden

\begin{tabular}{|c|c|c|}
\hline Kategori & Jumlah & Persentase (\%) \\
\hline \multicolumn{3}{|l|}{ Umur } \\
\hline 21-25 Tahun & 9 & $22.5 \%$ \\
\hline 26-30 Tahun & 19 & $47.5 \%$ \\
\hline 31-35 Tahun & 10 & $25.0 \%$ \\
\hline 36-40 Tahun & 2 & $5.0 \%$ \\
\hline \multicolumn{3}{|l|}{ Jenis Pekerjaan } \\
\hline Ibu RT & 29 & $72.5 \%$ \\
\hline PNS & 2 & $5.0 \%$ \\
\hline Wiraswasta & 9 & $22.5 \%$ \\
\hline Total & 40 & $100.0 \%$ \\
\hline
\end{tabular}

Dari tabel 1 dapat diketahui bahwa mayoritas umur responden 26-30 Tahun sebanyak 19 orang $(47.5 \%)$ dan minoritas umur responden 36-40 Tahun sebanyak 2 orang $(5.0 \%)$.
Berdasarkan pekerjaan mayoritas pekerjaan responden yang yang berprofesi sebagai IRT sebanyak 29 orang (72.5\%) dan minoritas responden yang berprofesi sebagai PNS sebanyak 2 orang $(5.0 \%)$. 
Tabel 2

Disitribus Frekuensi Variabel Pengetahuan Ibu, Sikap Ibu, Pendidikan Ibu, Pendapatan Keluarga, Jumlah Anggota Keluarga

\begin{tabular}{|c|c|c|}
\hline $\begin{array}{r}\text { Variabel } \\
\end{array}$ & Jumlah(n) & Persentase(\%) \\
\hline \multicolumn{3}{|l|}{ Pengetahuan Ibu } \\
\hline Baik & 29 & 72.5 \\
\hline Cukup & 6 & 15.0 \\
\hline Kurang & 5 & 12.0 \\
\hline \multicolumn{3}{|l|}{ Sikap Ibu } \\
\hline Positif & 30 & 75.0 \\
\hline Negatif & 10 & 25.0 \\
\hline \multicolumn{3}{|l|}{ Pendidikan Ibu } \\
\hline Pendidikan Dasar (SD-SMP) & 6 & 15.0 \\
\hline Pendidikan Menengah (SMA-SMK) & 31 & 77.5 \\
\hline Pendidikan Tinggi( D3-S1,S2) & 3 & 7.5 \\
\hline \multicolumn{3}{|l|}{ Pendapatan Keluarga } \\
\hline$>$ UMK 2.037 .000 & 10 & 25.0 \\
\hline UMK 2.037.000 & 0 & 0 \\
\hline$<$ UMK 2.037.000 & 30 & 75.0 \\
\hline \multicolumn{3}{|l|}{ Jumlah Anggota Keluarga } \\
\hline$\leq 4$ Orang & 29 & 72.5 \\
\hline 5-8 Orang & 11 & 27.5 \\
\hline$>8$ Orang & 0 & 0 \\
\hline \multicolumn{3}{|l|}{ Status Gizi } \\
\hline Gizi Baik & 30 & 75.0 \\
\hline Gizi Kurang & 8 & 20.0 \\
\hline Gizi Buruk & 2 & 5.0 \\
\hline Gizi Lebih & 0 & 0 \\
\hline Total & 40 & 100.0 \\
\hline
\end{tabular}

Berdasarkan tabel 2 diperoleh distribusi frekuensi pengetahuan ibu dari 40

responden, mayoritas responden pengetahuan baik sebanyak 29 orang $(72,5 \%)$, dan minoritas responden pengetahuan kurang 5 orang (12.0\%). Distribusi responden berdasarkan sikap ibu dari 40 responden, mayoritas responden bersikap positif sebanyak 30 orang (75.0\%), dan minoritas responden bersikap negatif 10 orang (25.0\%). Distribusi responden berdasarkan pendidikan ibu dari 40 responden, mayoritas responden berpendidikan SMA-SMK sebanyak 31 orang $(77.5 \%)$, dan minoritas responden berpendidikan tinggi 3 orang $(7.5 \%)$.

Distribusi responden berdasarkan pendapatan keluarga dari 40 responden, mayoritas responden berpendapatan di bawah UMK sebanyak 30 orang (75.0\%), dan minoritas responden berpendapatan di atas UMK 10 orang (25.0\%). Distribusi responden berdasarkan jumlah anggota keluarga dari 40 responden, mayoritas responden di bawah 4 orang sebanyak 29 orang $(72.5 \%)$, dan minoritas responden 58 orang sebanyak 11 orang (27.5\%). Berdasarkanstatus gizi dapat diketahui bahwa responden berdasarkan status gizi , mayoritas rangsangan status gizi baik sebanyak 30 orang $(75.0 \%)$ dan minoritas dengan status gizi yang buruk sebanyak 2 orang $(5.0 \%)$. 
Tabel 3

Hubungan Pengetahuan Ibu, Sikap Ibu, Pendidikan, Pendapatan, Jumlah Anggota Keluarga

\begin{tabular}{|c|c|c|c|c|c|c|c|c|c|c|c|}
\hline \multirow{2}{*}{ Variabel } & \multicolumn{10}{|c|}{ Status Gizi } & \multirow{2}{*}{$\begin{array}{c}p \\
\text { value }\end{array}$} \\
\hline & \multicolumn{2}{|c|}{ Gizi buruk } & \multicolumn{2}{|c|}{ Gizi kurang } & \multicolumn{2}{|c|}{ Gizi baik } & \multicolumn{2}{|c|}{ Gizi lebih } & \multicolumn{2}{|c|}{ Total } & \\
\hline Pengetahuan & $\mathbf{n}$ & $\%$ & $\mathbf{n}$ & $\%$ & $\mathbf{n}$ & $\%$ & $\mathbf{n}$ & $\%$ & $\mathbf{n}$ & $\%$ & \\
\hline Baik & 0 & 0 & 0 & 0 & 29 & 72,5 & 0 & 0 & 29 & 100 & \\
\hline Cukup & 0 & 0 & 5 & 12,5 & 1 & 2,5 & 0 & 0 & 6 & 100 & \\
\hline Kurang & 2 & 5 & 3 & 7,7 & 0 & 0 & 0 & 0 & 5 & 100 & \\
\hline Sikap ibu & & & & & & & & & & & \\
\hline Positif & 0 & 0 & 0 & 0 & 30 & 75 & 0 & 0 & 30 & 100 & \\
\hline $\begin{array}{l}\text { Negatif } \\
\text { Pendidikan }\end{array}$ & 2 & 5 & 8 & 20 & 0 & 0 & 0 & 0 & 10 & 100 & \\
\hline Dasar & 2 & 5 & 4 & 10 & 0 & 0 & 0 & 0 & 6 & 100 & \\
\hline Menengah & 0 & 0 & 4 & 10 & 27 & 67,5 & 0 & 0 & 31 & 100 & \\
\hline $\begin{array}{l}\text { Tinggi } \\
\text { Pendapatan }\end{array}$ & 0 & 0 & 0 & 0 & 3 & 7,5 & 0 & 0 & 3 & 100 & \\
\hline >UMK & 0 & 0 & 0 & 0 & 10 & 25 & 0 & 0 & 29 & 100 & \\
\hline $\begin{array}{l}<\text { UMK } \\
\text { Jumlah } \\
\text { anggota } \\
\text { keluarga }\end{array}$ & 2 & 5 & 8 & 20 & 20 & 50 & 0 & 0 & 11 & 100 & \\
\hline$\leq 4$ orang & 1 & 2,5 & 3 & 7,5 & 25 & 62,5 & 0 & 0 & 29 & 100 & \\
\hline 5-8 orang & 1 & 2,5 & 5 & 12,5 & 5 & 12,5 & 0 & 0 & 11 & 100 & \\
\hline
\end{tabular}

\section{Pembahasan \\ Hubungan Pengetahuan lbu dengan Status Gizi Pada Anak Balita}

Kesimpulannya ada hubungan Berdasarkan pengetahuan ibu dengan status gizi. Hasil penelitian terhadap 40 orang ibu yang mempunyai satu balita di Lingkungan 15 Kelurahan Pekan Labuhan Kecamatan Medan Labuhan, dari 29 responden pengetahuan ibu baik berstatus gizi baik sebanyak 29 responden (72,5\%).

Menurut asumsi peneliti, ibu yang berpengetahuan baik dengan status balita gizi baik disebabkan karena pengetahuan ibu tentang gizi yang baik akan mempengaruhi cara berpikir ibu dalam memberikan asupan gizi yang baik yang akhirnya anak akan memiliki status gizi baik, semakin tinggi pengetahuan seseorang maka semakin mudah dalam menerima informasi.

Dari hasil penelitian ibu yang pengetahuan cukup berstatus gizi kurang sebanyak 5 orang (12,5\%) dan responden berpengetahuan cukup berstatus gizi baik sebanyak 1 orang (2,5\%).

Menurut asumsi peneliti ibu yang berpengetahuannya cukup akan mempengaruhi cara berpikir dalam memberikan asupan gizi kepada balitanya, beberapa ibu kurang tahu dalam memberi makanan sehat sehingga mempengaruhi status gizi balita. Ibu lebih membiarkan anaknya makan makanan yang kurang sehat seperti jajan.

Dari hasil peneliti ibu yang pengetahuan kurang berstatus gizi kurang sebanyak 3 orang dan responden berpengetahuan kurang berstatus gizi buruk sebanyak 2 orang (5,0\%).

Menurut asumsi peneliti ibu yang berpengetahuannya kurang dalam pemberian makan terhadap balita tidak memenuhi syarat 4 sehat 5 sempurna akan menyebabkan anak berstatus gizi buruk, pengetahuan yang kurang tentang makanan sehat akan menimbulkan anggapan bahwa makanan yang sehat adalah makanan yang mahal dan sulit di dapatkan.

\section{Hubungan Sikap Ibu dengan Status Gizi Pada Anak Balita}

Ada hubungan berdasarkan sikap ibu dengan status gizi dari 30 responden sikap positif responden berstatus gizi baik sebanyak 30 orang $(75,0 \%)$. 
Menurut asumsi peneliti, sikap positif ibu baik berstatus gizi baik di sebabkan karena ibu selalu memberikan respon yang positif kepada balitanya seperti mendampingi anak setiap kali makan dan selalu menciptakan situasi yang menyenangkan setiap kali makan dan memberikan pariasi menu makanan sehingga anak memberikan respon yang positif kepada ibu berupa reaksi yang menyenangkan pada saat makan.

Dari 10 responden sikap negatif responden berstatus gizi kurang sebanyak 8 orang $(20,0 \%)$ dan responden dengan sikap negatif berstatus gizi buruk sebanyak 2 orang $(5,0 \%)$.

Menurut asumsi peneliti, ibu balita yang bersikap negatif dengan status gizi buruk disebabkan oleh ibu tidak memberikan rangsangan berupa sikap yang positif terhadap balitanya seperti, ibu tidak menciptakan situasi yang menyenangkan pada saat makan, ibu lebih sering membiarkan anak memilih membeli jajan dari pada memilih untuk makan, dan tidak membujuk balitanya sehingga anak memberikan reaksi yang negatif seperti tidak mau makan pada saat diberi makan.

\section{Hubungan Pendidikan lbu dengan Status Gizi Pada Anak Balita}

Ada hubungan berdasarkan pendidikan ibu dengan status gizi,dari 6 responden pendidikan dasar responden berstatus gizi kurang sebanyak 4 orang $(10,0 \%)$, dan berpendidikan dasarberstatus gizi buruk sebanyak 2 orang $(5,0 \%)$.

Menurut asumsi peneliti ibu yang hanya berpendidikan dasar tidak akan menjamin status gizi bagi anaknya, ibu juga tidak tahu tentang apa itu gizi, bagaimana memilih makanan bergizi, manfaat gizi bagi kehidupan dan tidak ada kesadaran untuk melakukan pemenuhan kebutuhan gizi agar hidupnya sehat.

Dari 31 responden berpendidikan menengah responden berstatus gizi baik sebanyak 27 orang $(67,5 \%)$, dan

responden berpendidikan menengah berstatus gizi kurang sebanyak 4 orang $(10,0 \%)$.

Menurut asumsi peneliti, ibu berpendidikan menengah kurang dalam menerima informasi kesehatan dan memilih asupan gizi yang baik buat anak balitanya, sehingga tidak paham dalam member menu makanan yang menarik, selain itu mereka kurang bisa mengatur konsumsi makanan yang sesuai dengan kebutuhan sehingga terjadi kekurangan zat gizi.

Dari 3 responden berpendidikan tinggi responden berstatus gizi baik sebanyak 3 orang $(7,5 \%)$.

Menurut asumsi peneliti, ibu berpendidikan tinggi dengan status gizi baik maka dapat mempengaruhi ibu dalam pemberian makanan pada anak balita. Ibu yang mempunyai pendidikan tinggi, diharapkan mempunyai daya terima yang lebih baik terhadap ilmu yang diterima sehingga diharapkan dapat dipraktikkan pada keluarga. lbu yang berpendidikan tinggi lebih mengerti dalam memberikan asupan makanan dengan pariasi yang lebih menarik sehingga anak balita berkeinginan makan dengan senang.

Tidak ada hubungan antara pendapatan keluarga dengan status gizi, dari 10 responden pendapatan keluarga >UMK 2.037.000 responden berstatus gizi baik sebanyak 10 orang $(25,0 \%)$.

Menurut asumsi peneliti tingkat pendapatan keluarga sangat mempengaruhi tercukupi atau tidaknya kebutuhan primer, sekunder, serta perhatian dan kasih sayang yang akan diperoleh anak. Status gizi yang baik penting bagi kesehatandan kesejahteraan setiap orang. Seseorang hanya akan cukup gizi jika makanan yang dimakan mampu menyediakan zat penting yang diperlukan tubuh.

\section{Hubungan Pendapatan dengan Status Gizi Pada Anak Balita}

Dari 30 responden pendapatan $<U M K$ 2.037.000 responden berstatus gizi baik sebanyak 20 orang $(50,0 \%)$ dan responden pendapatan <UMK 2.037 .000 berstatus gizi buruk sebanyak 2 orang $(5,0 \%)$.

Menurut asumsi peneliti tingkat pendapatan keluarga keadaan ekonomi keluarga yang kurang mampu merupakan faktor yang kurang mendukung bagi pertumbuhan dan perkembangan anak balita. Hal ini disebabkan karena tingkat pendapatan keluarga sangat berpengaruh terhadap konsumsi pangan kaluarga.

Hasil penelitian terhadap 40 orang ibu yang mempunyai 1 balita di Lingkungan 15 Kelurahan Pekan Labuhan Kecamatan Medan Labuhan, bahwa dari 29 responden jumlah anggota keluarga $<4$ orang responden berstatus gizi baik sebanyak 25 
orang $(62,5 \%)$, dan responden jumlah anggota keluarga $<4$ orang berstatus gizi buruk sdebanyak 1 orang $(2,5 \%)$.

Menurut asumsi peneliti banyaknya jumlah anggota keluarga/anak yang tinggal dalam satu rumah yang diasuh oleh seorang ibu yang menjadi beban keluarga tersebut dalam pembiayaan maupun dalam perawatan sehari-hari. Jumlah

anak dalam keluarga akan mempengaruhi pemenuhan kebutuhan nutrisi bagi anggota keluarga.

\section{Hubungan Jumlah Anggota Keluarga dengan Status Gizi Pada Anak Balita Di Lingkungan 15 Kelurahan Pekan Labuhan}

Ada hubungan antara jumlah anggota keluarga dengan status gizi, dari 11 responden jumlah anggota keluarga 5-8 orang responden berstatus gizi baik sebanyak 5 orang $(12,5 \%)$ dan responden jumlah anggota keluarga 5-8 orang berstatus gizi buruk sebanyak 1 orang $(2,5 \%)$.

Menurut asumsi peneliti jumlah anak dalam keluarga mempengaruhi ketersediaan pangan keluarga. Pada tingkat penghasilan yang berbeda akan menghasilkan tingkat ketersediaan pangan yang berbeda pula. Jumlah anak yang banyak pada keluarga dengan status ekonomi yang rendah mempunyai peluang anak menderita gizi buruk.Makin banyak anggota keluarga yang harus ditanggung akan semakin berat pula keluargatersebut memenuhi asupan nutrisi bagi anggotanya, apalagi ditambah dengan kondisi kenaikan hargabarang yang tidak seimbang dengan kenaikan pendapatan.

\section{KESIMPULAN}

Berdasarkan hasil penelitian dan pembahasan yang dilakukan dapat diambil kesimpulan mengenai Faktor-faktor yang berhubungan dengan anak balita

1. Ada hubungan yang signifikan antara pengetahuan ibu dengan status gizi pada balita

2. Ada hubungan yang signifikan antara sikap ibu dengan status gizi pada balita

3. Ada hubungan yang signifikan antara pendidikan ibu dengan status gizi pada balita

4. Tidak ada hubungan yang signifikan antara pendapatan keluarga dengan status gizi pada balita
5. Ada hubungan yang signifikan antara jumlah anggota keluarga dengan status gizi pada balita

\section{SARAN}

1. Mengadakan penyuluhan kesehatan secara rutin dengan memasukkan materi gizi yang seharusnya dipenuhi, dan penjelasan tentang kandungan zat gizi pada makanan, sebagai upaya melakukan pola hidup bersih dan sehat, dan pola makan yang baik, sehingga dapat mengurangi tingkat keparahan dan penyebaran penyakit yang lebih luas.

2. Sebaiknya ibu balita dengan anak balita gizi kurang dan gizi buruk lebih mengerti dalam memberikan asupan gizi yang baik pada anak,dan rajin berkunjung ke puskesmas sehingga kondisi berat badannya dapat terpantau dengan baik.

3. Mengadakan penyuluhan kesehatan secara rutin dengan memasukkan materi gizi yang seharusnya dipenuhi, dan penjelasan tentang kandungan zat gizi pada makanan, sebagai upaya melakukan pola hidup bersih dan sehat, dan pola makan yang baik, sehingga dapat mengurangi tingkat keparahan dan penyebaran penyakit yang lebih luas.

4. Sebaiknya ibu balita lebih giat mencari informasi tentang cara dalam pemberian makanan yang bergizi dan seimbang melalui petugas kesehatan, di posyandu, di puskesmas, maupun melalui media informasi. Sehingga pengetahuan tentang gizi menjadi meningkat dan penyakit pada anak tidak terjadi.

5. Mengkaji lebih dalam tentang pengetahuan ibu terhadap status gizi,sikap ibu, jumlah anggota keluarga dan Faktor-faktor lain yang berhubungan dengan status gizi pada balita untuk menyempurnakan penelitian ini.

\section{DAFTAR PUSTAKA}

Achadi, 2007.Cara Mendeteksi Gizi Buruk Pada Bayi. 2007 eJournal Keperawatan (e-kep) Volume 3 Nomor 1 Maret 2015 http://eprints.ums.ac.id/41448/15/.p 
df di akses pada tanggal 15 januari 2015

Almatsier.Sunita. 2009. Prinsip Dasar IImu Gizi. Jakarta: Gramedia Pustaka Utama.

Adriani Merryana dan Bambang Wirjatmadi. 2012. Pengantar Gizi Masyarakat. Jakarta: KENCANA.

Appriadji, Eicd Harry. 2008. Variasi Makanan Sehat Bagi Puspaswara. Jakarta

Arifin Zulhijah 2013. Hubungan pengetahuan dan sosial ekonomi dengan status gizi Balita di puskesmas lohia kecamatan lohia kabupaten muna Sulawesi tenggara, volume 2 Nomor 3 Tahun 2013.

Arikunto, 2006. Prosedur Penelitian. Rineka Cipta, Jakarta.

Arisman, 2009. Gizi Dalam Daur Kehidupan. Jakarta : Kedokteran EGC

Astuti, Fardhiasi Dwi dan Taurina Fitri Sulistyowati. 2012. Hubungan Tingkat Pendidikan Ibu dan Tingkat Pendapatan Keluarga Dengan Status Gizi Anak Prasekolah Dan Sekolah Dasar Di Kecamatan Godean :Fakultas Kesehatan Masyarakat,

Universitas Ahmad Dahlan,

Yogyakarta

:http://journal.uad.ac.id/index.php/Ke

sMas/article/viewFile/1048/pdf 3.

diakses pada tanggal 03 Mei 2015

Azwar, Saiffuddin. 2005, Sikap Manusia Teoridan Pengukurannya Edisi Kedua, Yogyakarta.

Berg, Alan. 2001. Peranan Gizi Dalam Pembangunan Nasional. Jakarta: CV. Rajawali.

Departemen Kesehatan RI, 2014, Pusat Data dan Informasi Kementrian RI. Hasil Riset Kesehatan Dasar (Riskesdas) 2010

DepKes RI. Hasil Ukur Status Gizi. Depkes RI 2002

Dinkes, Provinsi Sumatra Utara, 2015, Profil Kesehatan Propinsi Sumatra Utara

Dinas Kesehatan, 2015, Profil Gizi Kota Medan

Djola, Rolavensi. 2011. Hubungan Antara Tingkat Pendapatan Keluarga Dan Pola Asuh Dengan Status Gizi Anak Balita Di Desa Bongkudai Kecamatan Modayag Barat: Fakultas Kesehatan Masyarakat Universitas Sam
Ratulangi.http://fkm.unsrat.ac.id/wpcontent/uploads/2012/10/RolavensiDjola.pdf di aksespadatanggal 03 Mei 2015

Efriza, 2007.Deteminan kematian neonatal dini di RSUD dr Achmad Moechtar Bukit tinggi, Journal Kesehatan masyarakat Nasional, Volume 2 nomor 3 desember 2007, Fakultas Kesehatan Masyarakat Universitas Indonesia, Depok: http://jurnalkesmas.ui.ac.id/index.php /kesmas/article/view/264 di akses pada tanggal 10 Juni 2015

Faradevi, R. (2011). Perbedaan Besar Pengeluaran Keluarga, Jumlah Anak serta Asupan Energi dan Protein Balita antara Balita Kurus dan Normal. (Skripsi), Universitas Diponegoro, Semarang. Retrieved 22 Oktober 2013.

https://core.ac.uk/download/files/37 9/11731577.pdf di akses pada tanggal 20 Juni 2015

Furqon, Mohammad. 2008. Pentingnya Pengetahuan Gizi Bagi lbu dan Balita.

Hasbullah, 2012. Dasar-dasar ilmu Pendidikan. Raja Grafindo Persada (Rajawali Perss)

Hasmi. 2012. Metodelogi Penelitian Epidemiologi. Jakarta: Trans Info Media.

Hidayat A. Azis Alimul .A. 2008. Pengantar IImu Kesehatan Anak Untuk Pendidikan Kebidanan. Jakarta : Salemba Medika

Ihsan, Muhammad. 2012. Faktor-Faktor Yang Berhubungan Dengan Status Gizi Anak Balita Di Desa Teluk Rumbia Kecamatan Singkil Kabupaten Aceh Singkil Tahun 2012: Epidemiologi FKM USU http://download.portalgaruda.org/artic le.php?article $=51408 \& \mathrm{val}=4108 \mathrm{di}$ akses pada tanggal 12 Januari 2016

Jannah, Miftakhul. 2014. Hubungan Tingkat Pendidikan Ibu Dengan Status Gizi Balita di Posyandu Bangun sari Semin Gunung Kidul Tahun 2014: UniversitasDiponogorohttp:// jurnal.akbid-mu.ac.id di akses pada tanggal 10 februari 2016

Khotimah, Nur Nyimas. Dkk. Hubungan Pengetahuan Gizi Ibu Dan Pola Makan Balita Dengan Status Gizi 
Balita (12-59 Bulan) Di Wilayah Kerja Puskesmas Gandus

KecamatanGandus-Palembang Tahun 2010. Jurnal Pembangunan Manusia Vol.6 No.2 Tahun 2012

Laij, Joko. 2012. Hubungan Pendapatan Keluarga Terhadap Status Gizi Pada Balita Di Gorontalo Jakarta Timur Tahun 2012, Jurnal Pembangunan Manusia Vol.6 No.3 Tahun 2012 http://lib.unnes.ac.id/692/1/1263.pdf di akses pada tanggal 26 januari 2016

Maryunani Anik.2010. IImu Kesehatan Anak dalam Kebidanan. Jakarta: Trans Info Media.

Mubarak, lqbal Wahid dan Nurul Chayatin.2011. IImu Kesehatan Masyarakat Teori dan Aplikasi. Jakarta : Salemba Medika

Notoatmodjo, Soekidjo 2007. Kesehatan Masyarakat IImu dan Seni. Jakarta: Rhineka Cipta.

Notoatmodjo, Soekidjo 2010. Metodologi Penelitian Kesehatan. Jakarta :Rhineka Cipta

Nainggolan, Julita. 2010. Hubungan AntaraP engetahuan Dan Sikap Gizi Ibu Dengan Status Gizi Balita Di Wilayah Kerja Puskesmas Raja Basa Indah Kelurahan Raja Basa Raya Bandar Lampung. Fakultas Kedokteran Universitas Lampung http://jukeunila.com/MAJORITY/Volu me\%201\%20No.1/24-40-1-SM. pdf di akses pada tanggal 21 Januari 2016

Nyoman, 2002. Penilaian Status Gizi. Jakarta: Buku Kedokteran EGC

Olii, Suharni. 2010. Analisis Faktor-Faktor Yang Berpengaruh Terhadap Status Gizi Balita Di Pedesaan

Pahlevi Elisa Andriani, 2012. Determinan Status Gizi Pada Siswa Sekolah Dasar, Jurusan Ilmu Kesehatan Masyarakat, Fakultas IImu Keolahragaan, Universitas Negeri Semarang, Indonesia http://journal.unnes.ac.id/nju/index. php/kemas/article/view/2807 di akses pada tanggal 20Agustus 2015

Pome Gunardi, 2008.Faktor-Faktor Yang Berhubungan Dengan Status Gizi Balita Puskesmas Tanjung Agung Kecamatan Baturaja Barat Kabupaten Oku Tahun 2008
Program Studi Keperawatan Batu raja Poltekes Kemenkes Palembang

PuskesmasPekanLabuhan 2015

Profil Kesehatan Indonesia Tahun 2013, Data Balita Kekurangan gizi dan Gizi Buruk Tahun 2013.

Profil Kesehatan Kota Medan Tahun 2014.Data Status Gizi Balita Kota Medan Tahun 2014

Proverawati Atikah, dan Erna Kusuma Wati. 2011. Gizi untuk Kebidanan.Yogyakarta: Ruha Medika.

Pudjiadi, S. 2003. IImu Gizi Klinis Pada

Anak. Fakultas KedokteranUniversitas Indonesia.

Purwanto, Heri. 2010. Pengantar Prilaku Manusia Untuk Keperawatan. Jakarta : ECO

Rakhmawati, Zuraida Nuris. 2013. Hubungan Pengetahuan dan Sikap Ibu Dengan Perilaku Ibu Dalam Pemberian Makanan Anak Usia 1224 Bulan Semarang 2013. Artikel Penelitian

Siswoyo, Dwi. Dkk. 2008. Ilmu pendidikan. Yogyakarta

Soekirman, 2000. IImu Gizi dan Aplikasinya untuk Keluarga dan Masyarakat, Dep. Pendidikan Nasional. Jakarta.

Suhendri, Ucu. 2009. Faktor-faktor Yang Berhubungan Dengan Status Gizi Anak Balita Di Bawah Lima Tahun (BALITA) Di Puskesmas Sepatan Kecamatan Sepatan Kabupaten Tangerang Tahun 2009.

Sukirno, Sadono. 2005. Mikro Ekonomi Teori Pengantar. Jakarta : PT. Raja Grafindo Persada

Supariasa ,dkk. 2012. Penilaian Status Gizi. Jakarta: Buku Kedokteran EGC.

UU. No 10 Tahun 2014. Sumber Daya ManusiaBagiPembangunan Indonesia Nasional. http://www.dpr.go.id/dokjdih/docume nt/uu/UU_2007_17.pdf. Di akses pada tanggal 20 mei 2015

UU. No 20 tahun 2003 Tentang Sistem Pendidikan Nasional (Sisdiknas).http://sindikker.dikti.go.id/ dok/UU/UU20-2003-Sisdiknas.pdf. Di akses pada tanggal 20 agustus 2015

UMK.2015. Upah Minimum Kabupaten/Kota Medan. http://gajiumrumkterbaru.blogspot.co. id/2015/10/umk-medan-2016.html di 
akses pada tanggal 25 september 2015

Wawan, A. dan Dewi M. 2011.Teori dan Pengukuran Pengetahuan, Sikap, dan Prilaku Manusia.Yogyakarta NuhaMedika

World Health Organization. 2010. World Health Statistics. Status Gizi Pada Balita 